JINOTEP Vol 7 (2) (2020): 96-106

DOI: 10.17977/um031v7i22020p096

JINOTEP (Jurnal Inovasi Teknologi Pembelajaran)

Kajian dan Riset Dalam Teknologi Pembelajaran

http://journal2.um.ac.id/index.php/jinotep/index

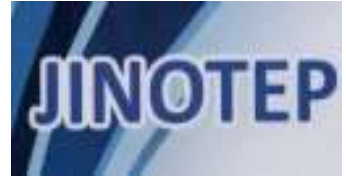

\title{
PENGEMBANGAN VIDEO ANIMASI PEMBELAJARAN SUBTEMA PEMBENTUKAN KARAKTER UNTUK SISWA SDLB TUNARUNGU
}

\author{
Dian Pradana, Zainul Abidin, Eka Pramono Adi \\ Jurusan Teknologi Pendidikan, Fakultas Ilmu Pendidikan, Universitas Negeri Malang \\ Jl. Semarang 5 Malang 65145-0341-575700 \\ dianpradana00@gmail.com
}

\section{Article History \\ Received: $30-07-2019$ \\ Accepted: 02-10-2019}

Published:1-10-2020

Keywords

Pengembangan

Video; Tunarungu;

Pembentukan karakter

\begin{abstract}
Abstrak
Setiap anak berhak mendapat pendidikan untuk mengembangkan potensi yang ada dalam dirinya, tidak terkecuali bagi mereka yang memiliki perbedaan dalam kemampuan atau yang sering disebut dengan istilah difabel. Pengembangan video animasi pembelajaran untuk siswa tunarungu bertujuan untuk menghasilkan, mengetahui kelayakan video animasi dan respon siswa tunarungu terhadap video animasi pembelajaran pembentukan karakter. Dalam penelitian ini menggunakan metode penelitian dan pengembangan Sadiman. Hasil dari pengembangan ini adalah sebuah video animasi pembelajaran pembentukan karakter. Penelitian ini memperoleh hasil dari ahli media 94\%, ahli materi 92\%, uji coba kelompok besar 91\%. Berdasarkan hasil tersebut, video animasi pembelajaran pada materi pembentukan karakter dinyatakan valid, layak dan cukup efektif digunakan dalam pembelajaran. Dengan demikian video animasi dapat digunakan untuk kebutuhan pembelajaran.
\end{abstract}

\begin{abstract}
Every child has the right to get an education to develop the potential that exists in him, not least for those who have differences in abilities or are often referred to as diffables. Development of learning animation videos for deaf students aims to produce, to know the feasibility of animated videos and the response of deaf students to animated character formation learning videos. In this study using research methods and development of Sadiman. The result of this development is an animation video for character building learning. This study obtained results from media experts $94 \%$, material experts 92\%, large group trials $91 \%$. Based on these results, learning animation videos on character building material were declared valid, feasible and quite effective to be used in learning. Thus, animated videos can be used for learning needs.
\end{abstract}

Corresponding author :

Adress: Jalan Teluk Grajakan No.5 Kec. Blimbing. Malang. Instansi: Teknologi Pendidikan, Universitas Negeri Malang E-Mail: dianpradana00@gmail.com
2020 Universitas Negeri Malang p-ISSN 2406-8780 e-ISSN 2654-7953 


\section{PENDAHULUAN}

Pendidikan sangatlah penting bagi semua manusia untuk mengembangkan potensi yang dimilikinya dan meningkatkan kualitas pendidikannya menjadi lebih baik. Oleh karena itu , pendidikan sangat penting untuk kemajuan kehidupan seseorang. Setiap anak berhak mendapat pendidikan untuk mengembangkan potensinya yang ada dalam dirinya, tidak terkecuali bagi mereka yang memiliki perbedaan dalam kemampuan atau disebut juga difabel. Layanan Pendidikan untuk anak yang berkelainan atau difabel bisa dapat menempuh pendidikan khusus pada tingkat pendidikan dasar sampai menengah. Ada beberapa golongan difabel yang bisa menjalani pendidikan di Sekolah Luar Biasa, salah satunya adalah tunarungu (Somantri, 2012; Wasita, 2012).

Tunarungu adalah seorang yang mengalami gangguan dalam kemampuan mendengar sebagian atau seluruhnya yang diakibatkan oleh tidak berfungsinya alat pendengaran sehingga orang tersebut tidak bisa memakai alat pendengarannya (Winarsih, 2007). Menurut (M Efendi, 2017; Mohammad Efendi, 2006), anak yang mengalami gangguan atau kelainan pendengaran disebut juga dengan tunarungu.

Penyebab tunarungu pada anak disebabkan oleh kerusakan atau gangguan pada organ telinga bagian luar, organ telinga bagian tengah, dan organ telinga bagian dalam yang disebabkan kecelakaan, penyakit, atau sebab lainnya yang tidak diketahui sehingga organ tersebut tidak dapat fungsi. Oleh karena itu, seorang difabel tunarungu memiliki keterbatasan dalam komunikasi (Asriani \& Susilawati, 2010) yaitu sukar melaksanakan komunikasi lisan (verbal) dengan orang lain sehingga pada umumnya tunarungu menggunakan bahasa isyarat untuk berkomunikasi. Bahasa isyarat yang digunakan di Indonesia ialah Sistem isyarat Bahasa Indonesia (SIBI).

Guru dituntut untuk mencapai tujuan pembelajaran sehingga guru mengembangkan aspek-aspek yang terdapat pada proses belajar mengajar menjadi lebih efektif untuk dilakukan di dalam maupun di luar pembelajaran. Menurut Hamalik (dalam (Panje, Sihkabuden, \& Toenlioe, 2016), yakni pembelajaran adalah urutan unsur-unsur yang meliputi manusiawi, material, fasilitas, perlengkapan, dan mekanisme yang saling mempengaruhi dan berkombinasi untuk mencapai tujuan pembelajaran. Menurut (Ardiansah, 2019; Mawarni, Mulyani, \& Yamtinah, 2014; Permatasari, Degeng, \& Adi, 2019; Setyaningrum \& Wiyatmo, 2016) media berfungsi untuk memperjelas, memudahkan, serta membuat sistem pembelajaran lebih menarik pada materi yang ingin diajarkan. Menurut Hills (dalam (Abdulhak, I. dan Darmawan, 2015; Susilana, Si, \& Riyana, 2008) media audio visual atau video adalah suatu representasi penyajian realitas, terutama melalui indra penglihatan dan pendengaran yang bertujuan untuk menampilkan pengalaman pendidikan yang nyata kepada peserta didik.

Menurut (Setyaningrum \& Wiyatmo, 2016) dalam penelitiannya yang berjudul "Pengembangan Video animasi pembelajaran Fisika Berbasis Sibi Pada Materi Getaran Dan Gelombang Sebagai Media Belajar Mandiri Untuk Meningkatkan Minat Belajar Pada Peserta Didik Tunarungu" dari penelitian tersebut diperoleh bahwa dengan menggunakan media pembelajaran video berbasis SIBI dalam proses pembelajaran sangat membantu untuk meningkatkan motivasi belajar peserta didik dalam belajar.

Menurut penelitian (Putri, Parmiti, \& Sudarma, 2020) yang berjudul "Pengembangan Video Pembelajaran Dengan Bahasa Isyarat Berbasis Pendidikan Karakter Pada Siswa Kelas V Di SDLB-B Negeri I Buleleng Tahun Pelajaran 2017/2018" dari penelitian tersebut diperoleh bahwa hasil belajar siswa meningkat sesudah menggunakan video pembelajaran dengan bahasa isyarat berbasis pendidikan karakter dari pada siswa yang sebelum menggunakan 
98 JINOTEP (Jurnal Inovasi dan Teknologi Pembelajaran) Kajian dan Riset dalam Teknologi Pembelajaran Vol.7, No.2, Oktober 2020, Hal.96-106

pembelajaran video pembelajaran dengan bahasa isyarat berbasis pendidikan karakter. Menurut penelitian (Rozie, 2014) menyatakan bahwa dari hasil penelitian mengenai media video pembelajaran daur air dapat meningkatkan proses dan hasil belajar IPA siswa kelas V SD Negeri Bintoro 02 Jember

Menurut (Armansyah, Sulton, \& Sulthoni, 2019; Artawan, 2010; Muzakki, Efendi, \& Manan, 2017) media animasi dalam proses pembelajaran biologi ternyata dapat meningkatkan motivasi dan hasil belajar peserta didik karena media animasi mempunyai kemampuan untuk memvisualisasikan sesuatu yang rumit atau komplek melalui stimulus audio visual yang akhirnya memberi hasil lebih baik untuk tugas-tugas seperti mengenali, menghubunghubungkan fakta dan konsep, dan mengingat kembali.

Video merupakan suatu media yang cocok dan efektif untuk membantu peserta didik dalam proses pembelajaran. Menurut (Luhulima, Degeng, \& Ulfa, 2018; Nurhayati, Harun, \& Lestari, 2014) penggunaan media video animasi pada materi kesetimbangan kimia memberikan pengaruh besar yang berarti media video-animasi ini memberikan pengaruh yang cukup signifikan terhadap peningkatan hasil belajar siswa.

Kegiatan pembelajaran terkadang mendapatkan suatu permasalahan seperti dalam proses pembelajaran, siswa kurang antusias dalam mengikuti pelajaran di dalam kelas serta kurangnya pemahaman peserta didik dalam menerima materi pembelajaran yang telah disampaikan oleh pengajar. Hal ini karena guru kurang memberikan pelengkap dalam mata pelajaran tematik subtema pembentukan karakter, sumber belajar hanya pada buku tematik. Disinilah media pembelajaran berupa video sangat dibutuhkan dalam membantu kegiatan pembelajaran di SDLBN Kedungkandang 4. Peneliti memberikan kesimpulan bahwa jika pembelajaran menggunakan video pembelajaran memberikan kelebihan tersendiri (Irwandani \& Juariyah, 2016).

Media video animasi juga merupakan sebuah bentuk teknologi, media video animasi juga dapat mendukung dalam proses pembelajaran. Kegiatan belajar yang dilakukan melalui pemanfaatan teknologi sebagai media pembelajaran akan memudahkan guru mengajar dalam menyampaikan materi dan mempermudah peserta didik untuk menerima materi. Video merupakan salah satu media pembelajaran yang cukup jitu dan memiliki kemampuan dalam mengakomodasi dan mengintegrasikan elemen-elemen multimedia seperti teks, gambar, animasi, dan audio sehingga mampu memberikan kemudahan belajar bagi siswa

Pemilihan media video animasi pembelajaran dengan subtema pembentukan karakter diharapkan dapat membantu proses mengajar. Media pembelajaran dapat dimanfaatkan sebagai media yang dapat memberikan stimulus pada siswa untuk meningkatkan kegiatan pembelajaran di sekolah. Dengan catatan media tersebut dipilih secara tepat dan sesuai sasaran dengan memperhitungkan ciri-ciri media dan karakteristik siswa.

Berdasarkan observasi kepada guru kelas 6 yang dilakukan pada tanggal 6 maret 2019 di SDLB Negeri Kedungkandang 4 ada beberapa masalah yang ditemukan sebagai berikut : 1) Kurangnya media yang mampu mendukung pembelajaran secara nyata, 2) Materi pada buku paket tematik yang sedikit juga berpengaruh terhadap pemahaman siswa, 3) kurangnya motivasi belajar siswa, 4) siswa membutuhkan media untuk belajar mandiri 5) Dilihat pada prakteknya guru masih menggunakan metode ceramah. Pembelajaran yang menggunakan cara konvensional selain kurangnya maksimal dalam memberikan materi dan kurang memenuhi kebutuhan peserta didik juga 
terasa membosankan (Irwandani \& Juariyah, 2016).

Dapat digambarkan bahwa media video animasi pembelajaran ini sangat cocok dikembangkan dalam pembelajaran ini. Media video pembelajaran ini dibuat agar siswa dapat memahami materi dengan memvisualisasikan materi. Melihat dari sarana dan prasarana di SDLB juga memadai untuk dilakukan proses pembelajaran menggunakan video pembelajaran. Dari observasi yang dilakukan, ditemukan fenomena siswa cenderung bosan dengan metode ceramah pada subtema pembentukan karakter. Maka itu pemilihan media video pembelajaran dirasa cocok dalam pembelajaran ini. Berdasarkan observasi yang telah dilakukan, subtema pembentukan karakter ini membutuhkan visualisasi guna mengembangkan proses berpikir siswa, bukan sebatas bayangan saja. Dengan menggunakan media video animasi pembelajaran siswa dapat gambaran nyata yang dibuat dengan menggunakan video animasi pembelajaran ini.

Berdasarkan latar belakang masalah adapun tujuan yang ingin dicapai dalam pembuatan pengembangan video ini adalah : menghasilkan media video animasi subtema Pembentukan Karakter untuk siswa tunarungu kelas VI SDLBN kedungkandang 4 dan mengetahui tingkat kelayakan video animasi pembelajaran Subtema Pembentukan Karakter kelas VI SDLBN kedungkandang 4.

\section{METODE}

Metode penelitian ini menggunakan model pengembangan Sadiman. Metode yang digunakan dalam pengembangan ini mengacu pada pengembangan media pendidikan menurut (Sadiman, 2009) dengan tahapan prosedur : 1) Identifikasi kebutuhan; 2) merumuskan tujuan; 3) pengembagan materi; 4) pengembangan alat evaluasi; 5) menyusun naskah; 6) produksi; 7) tes/uji coba, 8) revisi; 9) Media siap digunakan.

Berikut ini merupakan gambar model pengembangan media menurut Sadiman :

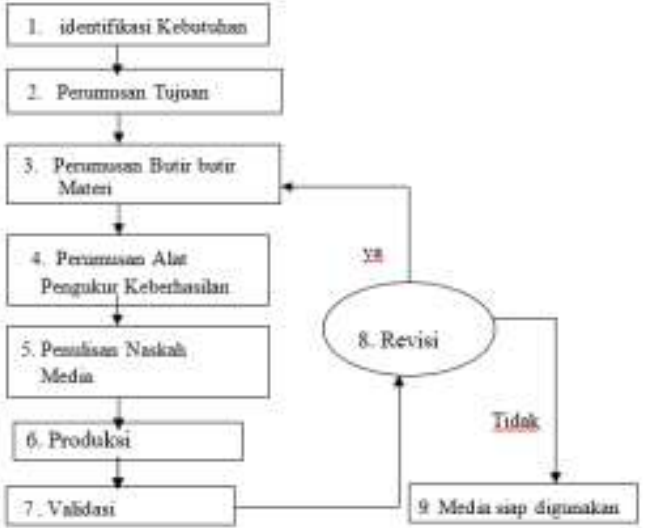

Gambar 1: Gambar langkah-langkah penelitian Sadiman (Arief, 2009)

Penelitian pengembangan ini

dilaksanakan di SDLB Negeri Kedungkandang 4 pada semester genap tahun ajaran 2018/2019. Peneliti memilih sekolah tersebut didasarkan pada hasil observasi pada tahap analisis kebutuhan. Analisis kebutuhan menunjukan bahwa guru dan siswa membutuhkan variasi media pembelajaran. Sedangkan subjek dalam penelitian ini adalah para ahli yang menguji kevalidan video animasi pembelajaran dengan menggunakan pendekatan kontekstual yang terdiri atas ahli media, ahli materi, audiens siswa kelas VI sebagai pengguna untuk melihat kesesuaian media yang dikembangkan. audiens siswa kelas VI SDLBN Kedungkandang 4 Malang sebagai pengguna untuk melihat tingkat kemenarikan, kemanfaatan, dan kemudahan, serta keefektifan video animasi pembelajaran materi tematik subtema pembentukan karakter dengan menggunakan pendekatan kontekstual.

Penelitian ini menggunakan prosedur pengembangan yang mengacu pada pengembangan media pendidikan menurut (Arief, 2009). Prosedur pengembangan dalam penelitian ini meliputi:

\section{Identifikasi Kebutuhan}

Berdasarkan observasi kepada guru kelas VI yang dilaksanakan pada tanggal 6 maret 2019 di SDLBN Kedungkandang 4 Malang, ada beberapa masalah yang ditemukan peneliti 1) Kurangnya media yang mampu mendukung pembelajaran secara nyata, 2) Materi pada buku paket tematik yang sedikit juga berpengaruh terhadap pemahaman siswa, 3) kurangnya motivasi belajar siswa, 4) siswa membutuhkan media untuk belajar mandiri 5) Dilihat pada prakteknya guru masih menggunakan metode ceramah. 
Dengan adanya media pembelajaran video animasi, diharapkan siswa terbantu dalam proses pembelajaran di kelas dan dapat mempelajari dengan mandiri. Serta dapat meningkatkan motivasi belajar siswa.

\section{Merumuskan Tujuan}

Tahap merumuskan tujuan pembelajaran merupakan tahap sesuatu yang penting dalam pencapaian pembelajaran. Ada dua jenis tujuan instruksional dalam pembelajaran yaitu, tujuan instruksional umum (kompetensi dasar) dan tujuan instruksional khusus (indikator). Tujuan instruksional umum merupakan tujuan akhir dari sesuatu kegiatan instruksional.Sedangkan tujuan instruksional khusus adalah penjelasan dari tujuan instruksional umum.

\section{Perumusan Butir - Butir Materi}

Dalam pengembangan video animasi pembelajaran ini tentang subtema pembentukan karakter. Dalam pengembangan materi menjadi sebuah naskah video berarti menuangkan materi kedalam tulisan. Materi yang dikembangkan tentang prinsip dasar pramuka dan semaphore. Tahapan pengembangan materi untuk menjadi naskah video sebagai berikut: (1) Menyusun identifikasi program, (2) Menyusun sinopsi, (3) Menyusun treatment, (4) Menyusun storyboard, (5) Menyusun naskah.

\section{Perumusan Alat Pengukur Keberhasilan}

Tahap Perumusan Alat Pengukur Keberhasilan adalah untuk mengukur tingkatan pemahaman siswa terhadap materi yang diajarkan. Alat ukur keberhasilan telah disusun berdasarkan jenis materi dan tujuan pembelajaran. Alat ukur keberhasilan ini disusun dalam bentuk tes tulis. Tes tulis digunakan mengukur hasil belajar siswa bentuk alat pengukur keberhasilan ini berupa pretest dan post-test. Sehingga peserta didik dapat mencapai tujuan pembelajaran yang diinginkan. Alat pengukur keberhasilan umumnya dapat berupa tes, penugasan.Sedangkan untuk mengukur kualitas dan validitas media video pembelajaran, digunakan teknik pengumpulan data berupa angket.Angket ini diberikan kepada ahli materi, ahli media dan audiens (peserta didik).

\section{Menyusun Naskah Media}

Tujuan menyusun naskah adalah sebagai acuan dalam membuat media yang nantinya akan digunakan sebagai acuan dalam produksi media. Langkah-langkah dalam menyusun naskah diantaranya (a) Merumuskan ide dan judul program, (b) Menentukan tujuan, (c) Mengidentifikasi karakteristik audiens, (d) Menyusun kerangka isi, meliputi sinopsis, treatment, dan storyboard, (e) Menentukan format program, (f) Penulisan naskah untuk lebih jelasnya terlampir pada bagian lampiran, (g) Produksi

Produksi merupakan proses pembuatan suatu media dengan berorientasi pada naskah. Produksi media video pembelajaran lebih dapat diartikan sebagai penggabungan materi -materi dengan pemanfaatan komputer untuk menggabungkan teks, grafik, audio, video, dan animasi menggunakan perangkat lunak Wondershare Filmora9 kemudian produk dikemas dalam bentuk keping DVD dengan desain yang menarik.

\section{Menyusun Petunjuk Pemanfaatan}

Petunjuk pemanfaatan disusun sebagai panduan pemakai (guru dan siswa) dalam mengajarkan isi pembelajaran kepada siswa. Untuk memudahkan dalam menggunakan video, maka disusun petunjuk pemanfaatan. Hal- hal yang perlu diperhatikan dalam menyusun petunjuk pemanfaatan yaitu: 1) identifikasi program, 2) petunjuk program, 3)cara penggunaan media, 4) dan penutup. Serta juga memperhatikan pemanfaatan media sebelum digunakan untuk pembelajaran, selama pembelajaran berlangsung dan perawatan media sesudah digunakan.

8. Validasi

\section{a. Validasi ahli}

Tahap validasi media dilakukan agar media pembelajaran yang dikembangkan dapat diketahui kelayakannya berdasarkan penilaian ahli materi dan ahli media. Instrumen yang digunakan oleh peneliti di ambil dari skripsi Anggit Priyambodo yang berjudul "Pengembanan Video Pembelajaran Ilmu Pengetahuan Alam Kelas VIII SMP Muhammadiyah 4 singosari “. Kegiatan penilaian pengembangan media video pembelajaran bertujuan untuk mengetahui apakah media yang di kembangkan tersebut layak untuk di gunakan dalam proses pembelajaran. Kegiatan validasi dilakukan oleh ahli media, ahli materi, dan audiens. Aspekaspek yang divalidasi kepada ahli media, ahli materi dan audiens meliputi kualitas teknis dan pemanfaatan media. Prosedur pelaksanaan 
validasi yaitu dengan memberikan angket instrumen validasi untuk diisi oleh ahli media, ahli materi dan audiens. Pengisian angket validasi ahli media dilakukan pada 23 April 2019, pengisian angket validasi ahli materi dilaksanakan pada 25 April 2019, dan pengisian angket validasi oleh siswa dilakukan pada $8 \mathrm{Mei}$ 2019.

\section{b. Teknis Analisis dan Interpretasi Data}

Teknik analisis dan interpretasi data yang digunakan adalah tes hasil belajar dan skor angket. Skor angket berupa penilaian yang diberikan ahli materi, ahli media dan audiens sedangkan skor hasil belajar diperoleh dari tugas yang diberikan kepada siswa. Data yang dihasilkan berupa deskripsi kualitatif, namun sebelum dideskripsikan data hams dianalisis terlebih dahulu dengan rumus :

$$
P=\frac{\text { jumlah keseluruhan jawaban responden }}{\text { skor maksimal }} \times 100
$$

Keterangan:

$$
\begin{aligned}
& \mathrm{P}=\text { Persentase } \\
& 100=\text { Konstanta }
\end{aligned}
$$

\section{Interpretasi hasil analisis}

Pedoman yang digunakan untuk menilai kelayakan video pembelajaran digunakan kriteria valid, cukup valid, kurang valid, dan tidak valid, yang akan dijabarkan pada kriteria kevaliditasan media pembelajaran sebagai berikut :

Tabel 1 adaptasi kriteria tingkat kelayakan (Arikunto, 2010).

\begin{tabular}{llll}
\hline Kategori & Persentase & Keterangan & Skor \\
\hline A & $76-100$ & Valid & 4 \\
B & $51-75$ & Cukup valid & 3 \\
C & $26-50$ & Kurang valid & 2 \\
D & $1-25$ & Tidak valid & 1 \\
\hline
\end{tabular}

\section{c. Analisis Data Tes Hasil Belajar}

Data skor tes hasil belajar dalam penelitian dan pengembangan ini diperoleh dari pelaksanaan tes setelah pembelajaran menggunakan video pembelajaran. Hasil tes masing-masing pebelajar dibandingkan dengan kriteria ketuntasan minimum (KKM) SDLBN Kedungkandang 4 Malang, mata pelajaran tematik kelas VI semester 2, dan KKM mata pelajaran tersebut adalah 60 . Untuk menganalisis data tes hasil belajar menggunakan rumus sebagai berikut :

$$
P=\frac{\text { jumlah siswa yang mencapai } K K M}{\text { jumlah siswa keseluruhan }} \times 100
$$

$$
\begin{aligned}
& \text { Keterangan : } \\
& \mathrm{P}=\text { Persentase } \\
& 100=\text { Konstanta }
\end{aligned}
$$

Hasil tersebut selanjutnya dikomunikasikan dengan tabel kriteria keefektifan berikut :

Tabe1 2 Kriteria Tingkat Keberhasilan (Arikunto, 2010).

\begin{tabular}{lll}
\hline Kategori & $\begin{array}{l}\text { Rentang } \\
\text { persentase }\end{array}$ & Keterangan \\
\hline A & $80-100$ & Efektif \\
B & $60-79$ & Cukup efektif \\
C & $40-59$ & Kurang efektif \\
D & $<40$ & Tidak efektif \\
\hline
\end{tabular}

Pembelajaran menggunakan video pembelajaran dikatakan efektif jika sebagian besar hasil dari tes belajar siswa mencapai 75 sesuai dengan (KKM) atau bahkan lebih dari KKM.

\section{Revisi}

Tahapan revisi akan dilakukan apabila media terdapat kekurangan atau belum memenuhi kriteria yang diharapkan setelah di validasi oleh ahli media dan ahli materi yang dilakukan bersamaan selanjutnya baru dilakukan revisi oleh audiens. Prosedur kegiatan revisi meliputi: (1) Melakukan validasi media kepada ahli media. (2) Jika ada revisi dari ahli media maka diperbaiki, apabila tidak ada revisi maka bisa dilanjutkan untuk validasi materi ke ahli materi. (3) Melakukan validasi materi kepada ahli materi. (4) Jika ada revisi dari ahli materi maka diperbaiki, apabila tidak ada revisi maka bisa dilanjutkan untuk validasi kepada siswa. (5) Melakukan validasi media video pembelajaran kepada siswa. (6) Produk Akhir.

\section{HASIL}

A. Hasil Penelitian

1. Penyajian dan analisis data ahli media

Validasi ahli media dilakukan untuk mengetahui kevalidan video animasi pembelajaran subtema pembentukan karakter untuk siswa tunarungu SDLB kelas VI . Ahli 
102 JINOTEP (Jurnal Inovasi dan Teknologi Pembelajaran) Kajian dan Riset dalam Teknologi Pembelajaran Vol.7, No.2, Oktober 2020, Hal.96-106

media yaitu dosen Teknologi Pendidikan. Hasil pengolahan data dari instrumen tentang video animasi pembelajaran

Persentase rata-rata nilai dari instrumen yang dipadatkan $94 \%$. Dari basil analisis, data selanjutnya dibandingkan dengan kriteria dapat diinterpretasikan bahwa video animasi pembelajaran tematik subtema pembentukan karakter kelas VI yang divalidasikan, menurut pendapat ahli media termasuk kategori A dengan kualifikasi valid dan layak untuk dimanfaatkan.

\section{Penyajian dan Analisis Data Ahli Materi}

Validasi ahli materi dilakukan untuk mengetahui kevalidan video animasi pembelajaran tematik subtema pembentukan karakter kelas VI. Ahli materi berjumlah satu orang yaitu dosen PLB Universitas Negri Malang . Hasil pengolahan data dari instrumen tentang video animasi pembelajaran :

Persentase rata-rata nilai dari instrumen yang dipadatkan adalah $92 \%$. Dari hasil analisis, data selanjutnya dibandingkan dengan kriteria dapat diinterpretasikan bahwa video animasi pembelajaran tematik subtema pembentukan karakter kelas VI yang di validasikan, menurut pendapat ahli materi termasuk kategori A dengan kualifikasi valid dan layak untuk dimanfaatkan.

\section{Hasil Uji Lapangan}

Uji coba Lapangan dengan 7 responden yaitu siswa kelas VI tunarungu di SDLBN Kedungkandang 4. Dari hasil penyajian data uji coba lapangan dapat diambil kesimpulan bahwa seluruh item pada video animasi pembelajaran termasuk kategori valid. Persentase rata-rata dari data table di atas adalah 91,8\%. Dari hasil analisis, data selanjutnya dibandingkan dengan kriteria dapat diinterpretasikan bahwa video animasi pembelajaran pembelajaran tematik subtema pembentukan karakter kelas VI yang di uji cobakan, menurut pendapat audiens atau siswa termasuk kategori A dengan kualifikasi valid dan layak untuk dimanfaatkan.

\section{Penyajian Data dan Analisis Tes Hasil Belajar}

Dari tes hasil belajar siswa yang dilakukan untuk mengetahui kelayakan video animasi pembelajaran yang dikembangkan. Terdapat 21 butir pernyataan yang terbagi dalam 3 aspek, yaitu: aspek materi, aspek media dan kemanfaatan.

belajar siswa dapat dianalisis dan diinterpretasikan dari 7 responden yang mengikuti tes hasil belajar, 6 responden mengalami ketuntasan belajar atau memenuhi KKM setelah menonton video pembelajaran subtema pembentukan karakter, sedangkan 1 responden dinyatakan belum tuntas atau tidak memenuhi KKM. Uji coba 7 sampel ini didapatkan jumlah nilai sebesar 495 dengan ratarata sebesar $70.7 \%$. hasil pengolahan data diatas maka didapatkan hasil jumlah peserta didik yang mencapai KKM sebesar $85.7 \%$ dan jumlah peserta didik yang tidak melampaui KKM sebesar $14.2 \%$. hal ini menunjukan bahwa video animasi pembelajaran efektif digunakan dalam proses pembelajaran klasikal

\section{PEMBAHASAN}

Menurut

(Artawan,

2010

Istiqomatunnisa \& Kuswandi, D., 2018) media animasi dalam proses pembelajaran biologi ternyata dapat meningkatkan motivasi dan hasil belajar peserta didik karena media animasi mempunyai kemampuan untuk memvisualisasikan sesuatu yang rumit atau komplek melalui stimulus audio visual yang akhirnya memberi hasil lebih baik untuk tugastugas seperti mengingat, mengenali, mengingat kembali dan menghubung-hubungkan fakta dan konsep. Video merupakan suatu media yang sangat efektif untuk membantu peserta didik dalam proses pembelajaran.

Menurut (Muslimin, 2017) dalam penelitiannya yang berjudul Pengaruh Penggunaan Media Pembelajaran Video Animasi Terhadap Hasil Belajar Pendidikan Kewarganegaraan Kelas II SD. Berdasarkan hasil penelitian diperoleh kesimpulan yaitu ada pengaruh penggunaan media video animasi terhadap hasil belajar Pendidikan Kewarganegaraan siswa kelas II B SD Muhammadiyah Karangtengah Bantul Yogyakarta. Hal ini ditunjukkan dengan adanya peningkatan nilai rata-rata Pendidikan Kewarganegaraan pada materi tolong-menolong pretest sebesar 65,97 menjadi nilai rata-rata posttest sebesar 76,84 sesudah diberi perlakuan menggunakan media pembelajaran video animasi. Terjadi peningkatan juga pada jumlah siswa yang nilainya sudah mencapai KKM yaitu dari 7 siswa menjadi 15 siswa. Selisih skor mean posttest dan mean pretest sebesar 10,87. Dengan kata lain, pemahaman siswa terhadap materi Pendidikan Kewarganegaraan antara setelah 
mendapat perlakuan menggunakan media video animasi menjadi lebih tinggi daripada sebelum mendapat perlakuan menggunakan media video animasi.

Kualitas produk video animasi yang dikembangkan dapat digolongkan sangat baik. Hal ini terbukti dari hasil validasi ahli materi, ahli media serta uji coba produk yang memperoleh dari angket dengan memberikan kesan bahwa produk video animasi pembelajaran yang dikembangkan menarik, praktis dan memudahkan dalam memahami materi larutan penyangga.

Uji validasi ahli media dilakukan untuk mengetahui kelayakan media dalam video animasi pembelajaran yang dikembangkan. Terdapat 25 butir pernyataan yang terbagi dalam 2 aspek, yaitu: aspek media, dan kemanfaatan dari hasil uji validasi aspek media mendapatkan hasil persentase 93,4\% dan kemanfaatan mendapatkan hasil persentase $100 \%$.

Dari validasi ahli media mendapatkan total skor total sebesar 94. Seluruh data penilaian dari validator ahli media diakumulasi dan diolah mendapatkan hasil sebesar persentase 94\%. Hasil tersebut dapat diinterpretasikan bahwa video animasi pembelajaran termasuk dalam kategori sangat layak digunakan.

Uji validasi ahli materi dilakukan untuk mengetahui kelayakan materi dalam video animasi pembelajaran yang dikembangkan. Terdapat 25 butir pernyataan yang terbagi dalam 2 aspek, yaitu: aspek kesesuaian materi, aspek media. Dari hasil uji validasi aspek media mendapatkan hasil persentase $92,3 \%$ dan aspek media mendapatkan hasil persentase $87,5 \%$.

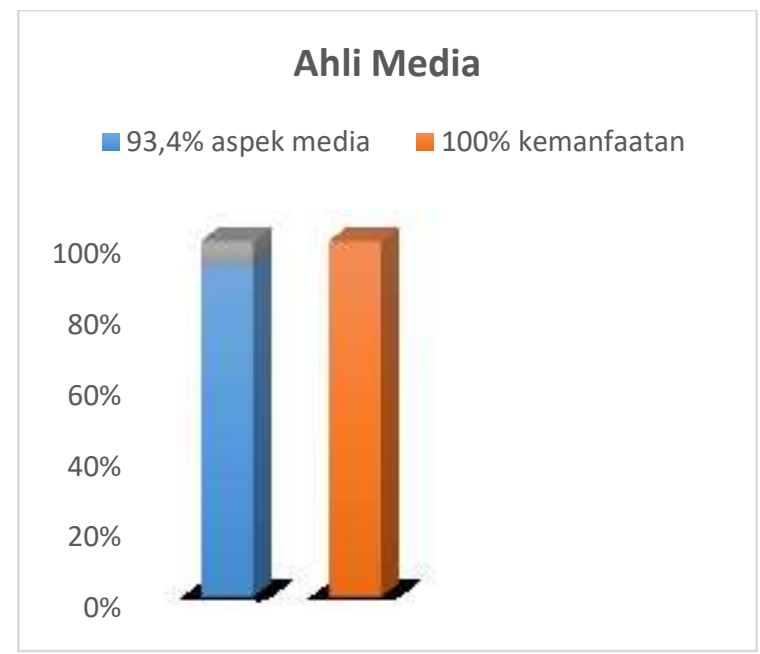

Gambar 2. Hasil validasi ahli media
Ahli Materi

-92,3\% aspek materi $\quad 87,5 \%$ aspek media

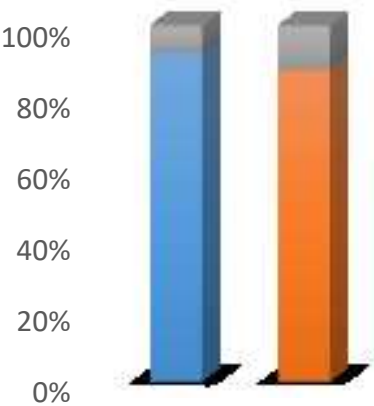

Gambar 3. Hasil validasi ahli materi

Validasi ahli materi mendapatkan total penilaian secara keseluruhan sebesar 92. Seluruh data penilaian dari validator ahli media diakumulasi dan diolah mendapatkan hasil sebesar persentase 92\%. Hasil tersebut dapat diinterpretasikan bahwa video animasi pembelajaran termasuk dalam kategori layak untuk dimanfaatkan.

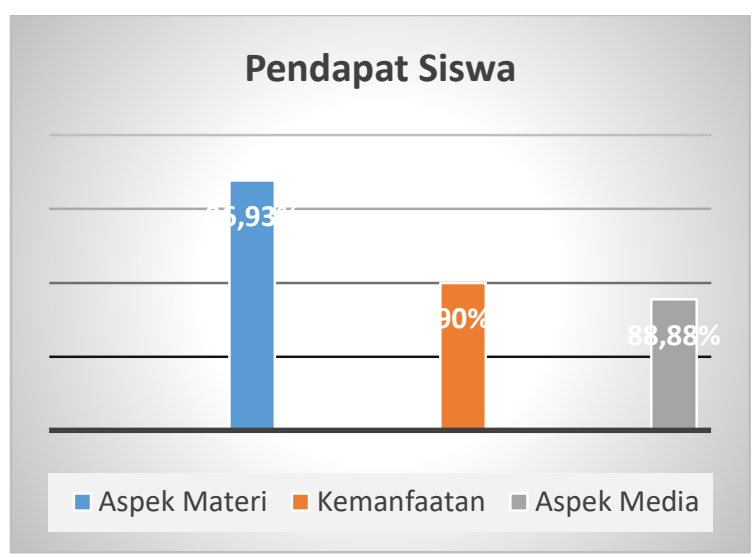

Gambar 4. Persepsi pengguna terhadap produk

Pendapat siswa dilakukan untuk mengetahui kelayakan video animasi pembelajaran yang dikembangkan. Terdapat 21 butir pernyataan yang terbagi dalam 3 aspek, yaitu: aspek materi, aspek media dan kemanfaatan.

Tahap selanjutnya yaitu uji coba pada kelompok besar yang dilakukan pada 7 siswa kelas VI tunarungu. Uji coba kelompok besar mendapatkan hasil total skor 540. Dari data hasil uji coba kelompok besar kemudian diolah mendapatkan hasil dengan persentase sebesar 91\%. Hasil tersebut dapat diinterpretasikan bahwa video animasi pembelajaran termasuk dalam kategori sangat layak digunakan. 


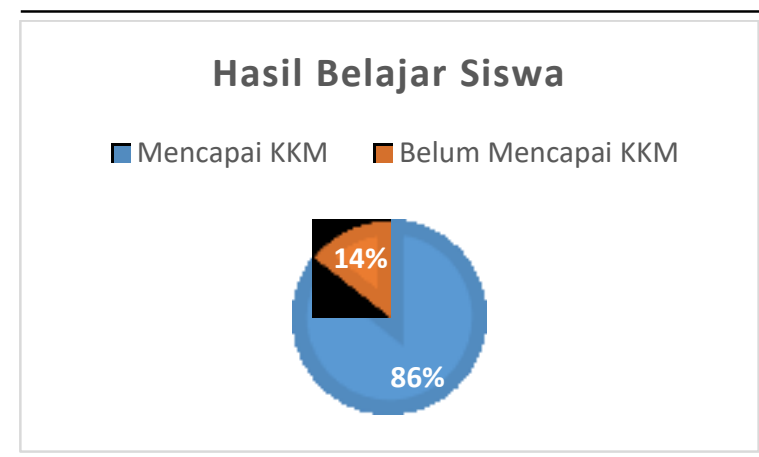

Gambar 5. Capaian hasil belajar siswa

Hasil belajar siswa dapat dianalisis dan diinterpretasikan dari 7 siswa yang mengikuti tes hasil belajar, 6 siswa mengalami ketuntasan belajar atau memenuhi KKM setelah menonton video pembelajaran subtema pembentukan karakter, sedangkan 1 siswa dinyatakan belum tuntas atau tidak memenuhi KKM. Uji coba 7 sampel ini didapatkan jumlah nilai sebesar 495 dengan rata-rata sebesar $70.7 \%$. hasil pengolahan data di atas maka didapatkan hasil jumlah peserta didik yang mencapai KKM sebesar $85.7 \%$ dan jumlah peserta didik yang belum melampaui KKM sebesar $14.2 \%$. hal ini menunjukan bahwa video animasi pembelajaran efektif digunakan dalam proses pembelajaran klasikal.

Secara umum capaian hasil belajar siswa dan hasil analisis diatas, terlihat bahwa video animasi pembelajaran subtema pembentukan karakter ini cukup efektif untuk meningkatkan hasil belajar siswa. Hal tersebut memberikan masukan kepada para guru untuk menggunakan dalam proses pembelajaran.

Di era teknologi informasi dan komunikasi saat ini para guru dituntut kreatif dan inovatif dalam merancang dan mengembangkan bahan ajar yang menarik untuk para peserta didiknya. Optimalisasi pemanfaatan teknologi dalam pembelajaran merupakan pilihan yang bijak (Praherdhiono et al., 2019). Namun demikian para guru tetap harus cermat memilih dan memilah media dan sumber belajar yang tepat mengingat karakter peserta didik berkebutuhan khusus berbeda dengan peserta didik pada umumnya.

Saat ini ada beragam media dan sumber belajar teknologis yang dapat dimanfaatkan untuk meningkatkan mutu pembelajaran seperti media dalam bentuk konten mikro (Park \& Kim, 2018; Surahman, Ulfa, et al., 2019). Apabila pendidik memungkinkan mengembangkan pembelajaran daring maka pilihan model pembelajaran daring adaptif merupakan alternatif yang bijak untuk digunakan. Sehingga konten yang disajikan dapat disesuaikan dengan kebutuhan peserta didik. Misalnya pendidikan tunarungu maka dapat disajikan konten visual dengan bahasa yang dapat dipahaminya (Surahman, Kuswandi, Wedi, Thaariq, \& Diana, 2019).

\section{SIMPULAN}

Dengan menggunakan media video animasi ini menarik perhatian peserta didik sehingga peserta didik lebih tertarik mengikuti pembelajaran. Kelayakan media pembelajaran video pembelajaran subtema pembentukan karakter berdasarkan penilaian dari ahli media dan ahli materi termasuk kedalam kategori sangat layak, Hal ini menunjukkan bahwa video pembelajaran materi subtema pembentukan karakter yang dikembangkan dapat diterima sebagai media yang dapat digunakan dalam pembelajaran.

Respon siswa terhadap media pembelajaran video animasi pembelajaran subtema pembentukan karakter yang dilakukan pada uji siswa mendapatkan penilaian dengan persentase 91\%. Hal ini menunjukkan bahwa ketertarikan siswa pada media dan media tersebut dapat terima oleh siswa tunarungu dan dapat digunakan dalam pembelajaran. Dan dari hasil tes hasil belajar siswa terhadap video animasi pembelajaran subtema pembentukan karakter mendapatkan hasil jumlah peserta didik yang mencapai KKM sebesar $85.7 \%$ dan jumlah peserta didik yang belum mencapai KKM sebesar $14.2 \%$. hal ini menunjukan bahwa video animasi pembelajaran efektif digunakan dalam proses pembelajaran klasikal.

\section{DAFTAR RUJUKAN}

Abdulhak, I. dan Darmawan, D. (2015). Teknologi Pendidikan. Bandung: PT. Remaja Rosdakarya.

Ardiansah, F. (2019). Pengaruh Penggunaan Media Video Terhadap Minat dan Hasil Belajar Siswa Kelas XI pada Pelajaran PAI di SMA YPI Tunas Bangsa Palembang. Jurnal Kajian Teknologi Pendidikan.

Arief, S. (2009). Media Pendidikan, Pengertian, Pengembangan, dan Pemanfaatannya. Jakarta: PT. Rajagrafindo Persada. 
Armansyah, F., Sulton, S., \& Sulthoni, S. (2019). Multimedia Interaktif Sebagai Media Visualisasi Dasar-Dasar Animasi. Jurnal Kajian Teknologi Pendidikan, pp. 224-229. https://doi.org/10.17977/um038v2i32019p224

Artawan. (2010). Media Animasi. Jakarta: Yrama Widya.

Asriani, F., \& Susilawati, H. (2010). Pengenalan Isyarat Tangan Statis pada Sistem Isyarat Bahasa Indonesia Berbasis Jaringan Syaraf Tiruan Perambatan Balik. Makara Journal of Technology, 14(2).

Efendi, M. (2017). Studi Multikasus: Epidemi Perilaku Merorok di Kalangan Remaja dan Implikasinya dalam Pendidikan. Edcomtech Jurnal Kajian Teknologi Pendidikan, 1(1), 6982.

Efendi, Mohammad. (2006). Pengantar psikopedagogik anak berkelainan. Jakarta: Bumi Aksara.

Irwandani, I., \& Juariyah, S. (2016). Pengembangan media pembelajaran berupa komik fisika berbantuan sosial media instagram sebagai alternatif pembelajaran. Jurnal Ilmiah Pendidikan Fisika Al-Biruni, 5(1), 33-42.

Istiqomatunnisa, N., \& Kuswandi, D., A. J. E. T. (2018). Aplikasi Android Al-Amtsal (Kisah Teladan) Sebagai Media Pembelajaran Mengenal Kisah Al-Quran dengan Cerita Animasi Bagi Anak Generasi Alfa. Jurnal Kajian Teknologi Pendidikan, 1(1), 35-42.

Luhulima, D. A., Degeng, N. S., \& Ulfa, S. (2018). Pengembangan Video Pembelajaran Karakter Mengampuni Berbasis Animasi Untuk Anak Sekolah Minggu. JINOTEP (Jurnal Inovasi Dan Teknologi Pembelajaran) Kajian Dan Riset Dalam Teknologi Pembelajaran, 3(2), 110-120.

Mawarni, E., Mulyani, B., \& Yamtinah, S. (2014). Penerapan peer tutoring dilengkapi animasi macromedia flash dan handout untuk meningkatkan motivasi berprestasi dan prestasi belajar siswa kelas xi ipa 4 sman 6 surakarta tahun pelajaran 2013/2014 pada materi kelarutan dan hasil kali kelarutan. Jurnal Pendidikan Kimia, 4(1), 29-37.

Muslimin, M. I. (2017). Pengaruh Penggunaan Media Pembelajaran Video Animasi Terhadap Hasil Belajar Pendidikan Kewarganegaraan Kelas II SD. E-Jurnal Skripsi Program Studi Teknologi Pendidikan, 6(1), 26-34.

Muzakki, M., Efendi, M., \& Manan, A. (2017). Pengembangan Media Animasi Pembelajaran Interaktif Pokok Bahasan Gaya Pada Mata pelajaran IPA Kelas IV SD. Edcomtech Jurnal
Kajian Teknologi Pendidikan.

Nurhayati, S., Harun, A. I., \& Lestari, I. (2014). Pengaruh video-animasi terhadap hasil belajar siswa kelas XI SMAN 5 Pontianak pada materi kesetimbangan kimia. Jurnal Pendidikan Dan Pembelajaran Khatulistiwa, 3(6).

Panje, M., Sihkabuden, S., \& Toenlioe, A. J. E. (2016). Pengembangan Video Pembelajaran Bahasa Indonesia Teknik Membaca Puisi. Jurnal Pendidikan: Teori, Penelitian, Dan Pengembangan, 1(8), 1473-1478.

Park, Y., \& Kim, Y. (2018). A design and Development of micro-Learning Content in eLearning System. International Journal on Advanced Science, Engineering and Information Technology, 8(1), 56-61.

Permatasari, K., Degeng, I. N. S., \& Adi, E. P. (2019). Pengembangan Suplemen Video Pembelajaran Adaptasi Makhluk Hidup untuk Siswa Tunarungu SLB-B YPLB Blitar. Jurnal Kajian Teknologi Pendidikan, 2(4), 268-277.

Praherdhiono, H., Setyosari, P., Degeng, I. N. S., Slamet, T. I., Surahman, E., Adi, E. P., ... Abidin, Z. (2019). Teori dan Implementasi Teknologi Pendidikan: Era Belajar Abad 21 dan Revolusi Industri 4.0. Seribu Bintang.

Putri, N. M. L. K., Parmiti, D. P., \& Sudarma, I. K. (2020). Pengembangan Video Pembelajaran dengan Bahasa Isyarat Berbasis Pendidikan Karakter pada Siswa Kelas V di SDLB-B Negeri I Buleleng Tahun Pelajaran 2017/2018. Jurnal EDUTECH Undiksha, 7(2), 81-91.

Rozie, F. (2014). Development of Recycling Water Media Video Learning to Improve Processes and Learning Outcomes IPA Elementary Students. Jurnal Pendidikan Sains, 1(4), 413424.

Sadiman, A. S. (2009). Media Pendidikan pengertian, pengembangan dan pemanfaatannya.

Setyaningrum, A., \& Wiyatmo, Y. (2016). Pengembangan Video Pembelajaran Fisika Berbasis Sibi Pada Materi Getaran Dan Gelombang Sebagai Media Belajar Mandiri Untuk Meningkatkan Minat Belajar Pada Peserta Didik Tunarungu. Jurnal Pendidikan Fisika, 5(1), 38-45.

Somantri, S. (2012). Psikologi anak luar biasa,(cetakan ke 4). Bandung: Refika Aditama.

Surahman, E., Kuswandi, D., Wedi, A., Thaariq, Z. Z. A., \& Diana, R. C. (2019). Model Design of Adaptive Learning Analytics Management System (ALAMS) Using AID Model. The 4th International Conference on Education and Management (COEMA 2019). Atlantis Press. 
106 JINOTEP (Jurnal Inovasi dan Teknologi Pembelajaran) Kajian dan Riset dalam Teknologi Pembelajaran Vol.7, No.2, Oktober 2020, Hal.96-106

Surahman, E., Ulfa, S., Husna, A., Slamet, T. I., Qolbi, M. S., Setiawan, A. B., ... Diana, R. C. (2019). The Effect of Blended Training Model to Improving Learning Outcomes: A Case in Micro Learning Object Training. 2019 5th International Conference on Education and Technology (ICET), 33-38. IEEE.

Susilana, R., Si, M., \& Riyana, C. (2008). Media pembelajaran: hakikat, pengembangan, pemanfaatan, dan penilaian. CV. Wacana Prima.

Wasita, A. (2012). Seluk-Beluk Tunarungu dan Tunawicara Serta Strategi Pembelajarannya. Jogjakarta: Javalitera.

Winarsih, M. (2007). Intervensi dini bagi anak tunarungu dalam pemerolehan bahasa. Jakarta: Departemen Pendidikan Dan Kebudayaan. 